\title{
Nature and Duration of Protective Antibodies Developed After COVID-19 Infection
}

\author{
COVID-19 Enfeksiyonu Sonrası Gelişen Antikorların \\ Niteliği ve Koruyuculuk Süresi
}

\author{
Cansu Turan'(iD), Mustafa Hacımustafaoğlu'(iD) \\ ${ }^{1}$ Division of Pediatric Infectious Diseases, Department of Pediatrics, Uludag University School of Medicine, Bursa, Turkey
}

Question: An adolescent patient, who does not know whether he has had the disease or not and who has also not been vaccinated, has been tested for COVID-19 voluntarily. The test is positive. Will he be protected from the disease? Dr. Raşit Öztürk

Cite this article as: Turan C, Hacımustafaoğlu M. Nature and duration of protective antibodies developed after COVID-19 infection. J Pediatr Inf 2021;15(1):e58-e61.

\section{Answer (Cansu Turan, MD; Mustafa Hacımustafaoğlu, MD)}

COVID-19 infection can be asymptomatic or with mild clinical findings. In addition, its clinical findings can be very similar to other respiratory tract infections. Therefore, in some cases, the presence of specific antibodies may suggest previous COVID-19 infection even if without symptomatic infection. In order to give a detailed and appropriate answer to this question, it is useful to know some issues such as the type of antibody measured, neutralizing properties of the antibodies, and how long the antibody response continues.

Targeted antigen and/or antibody types by the different antibody tests used: SARS-CoV-2 has some different antigenic structures such as nucleoprotein (N), envelope (E), matrix (M), and spike (S) proteins. Commercial tests usually measure antibodies against the nucleoprotein or $\mathrm{S}$ proteins. The $S$ protein assumes the most important role in pathogenesis of COVID-19, and it plays a role in binding to ACE receptors in the host cell. In addition, antibodies developing against the $\mathrm{S}$ protein are protective. There are different measurement tests that measure SARS-CoV-2 antibodies. These tests can measure IgM or IgG antibody levels individually, as well as measure the total (lgM+lgG) antibody levels. The specificity of tests that measure $\lg G$ antibody or $\lg M+\lg G$ total antibodies is much higher than tests that measure $\lg M$ or $\lg \mathrm{A}$ antibodies alone. Therefore, the measurement of $\lg \mathrm{A}$ antibody level is not recommended for routine use. Similarly, the Infectious Diseases Society of America (IDSA) recommends using tests that measure only lgG or total antibody levels instead of tests that measure $\lg \mathrm{M}$ or $\lg \mathrm{A}$ antibodies. For this reason, the fact that the test examined is an lgG or total $(\lg G+\lg M)$ test makes it easy to evaluate.

Possibility of false antibody positivity of the different tests used: In some antibody tests, antibodies developing against other seasonal coronaviruses may also give false positives results for the antibodies against SARS-CoV-2 and by creating cross reactions. In some people who have not had COVID-19 infection, neutralizing antibodies against SARSCoV-2 and as well as reactive CD4 T cells against SARS-CoV-2

\section{Correspondence Address / Yazışma Adresi \\ Mustafa Hacımustafaoğlu \\ Uludağ Üniversitesi Tıp Fakültesi, \\ Çocuk Sağlığı ve Hastalıkları Anabilim Dalı, \\ Çocuk Enfeksiyon Hastalıkları Bilim Dalı, \\ Bursa-Türkiye \\ E-mail: mkemal@uludag.edu.tr}

Received: 10.02 .2021

Accepted: 21.02 .2021
Available Online Date: 02.04 .2021

๑Copyright 2021 by Pediatric Infectious Diseases and Immunization Society. Available online at www.cocukenfeksiyon.org 
have been detected. This situation has been thought to be due to cross antigen positivity developing after seasonal coronaviruses. For SARS-CoV-2 antibody tests, this cross positivity induced by seasonal coronavirus infections other than SARS-CoV-2, reduces the specificity of the tests. Therefore, the tests to be used for diagnostic purposes should be above a certain specificity and sensitivity limits and be standardized. The Centers for Disease Control and Prevention (CDC) recommends that antibody tests with high specificity $(99.5 \%)$ should be preferred primarily in the diagnosis of COVID-19. Therefore, the high sensitivity of the test used (the positive rate of a given test in a PCR confirmed COVID-19 patient) and high specificity (the negative rate of a given test in a patient without COVID-19) increases the accuracy of the test used.

The quality of a test to be used should also be taken into account: $A$ variety of serological tests have been used in serological antibody studies, such as commercially available or non-commercial/laboratory developed (in-house laboratory tests). Their sensitivities and specificities can vary widely. Rapid diagnostic tests (such as lateral flow tests, lateral flow assays); are less sensitive than ELISA tests or chemiluminescent immunoassays. Antibody tests using the ELISA or electrochemiluminescence immunoassay (ECLIA) methods are generally considered reliable. In the ECLIA method, it has been reported that automating system reduces user and operational errors, and therefore gives more specific and accurate results compared to ELISA.

Antibody based protection from disease prevention: Whether the presence of antibody levels is protective from the disease or not and the information on the duration of antibody responses to SARS-CoV- 2 in regard of the immunity are limited. In addition, some important parameters of the antibodies, such as the presence of antibodies that develop after infection, their levels (concentrations), how long they remain, and whether they are neutralizing and protective are also important. The duration of antibodies may depend on the high initial response and probably the severity of the infection. In many patients with COVID-19, neutralizing antibodies develop mainly against the receptor binding domain (RBD) of the $S$ protein. Measurement of protective neutralizing antibodies, requires biosafety level 3 laboratory conditions. Also, neutralizing antibody measurement is both difficult and expensive. Studies have shown that neutralizing antibody levels are correlated with anti-S and also anti-N antibody levels. There are studies reporting that this correlation is better with anti-S antibodies. Therefore, it can be thought that especially the presence of anti-S antibodies is associated with protection from disease. This means that the measured high titer antibody positivity may also indicate protective immunity. However, the protective antibody titer has not been clearly determined yet.
The tests used for antibody measurement can be qualitative, semi-quantitative or quantitative nature. Qualitative tests are the tests that report positive results above a certain threshold value (cut-off index; COI). In these tests, in practice, the current antibody concentration cannot be determined realistically. On the other hand, in quantitative tests, antibody concentrations (such as low or high) can also be determined. In quantitative measurements, different units (such as RU; relative unit, IU; international unit, BAU; binding antigen unit) can be used in different tests. For a given quantitative test, the concentrations of different patients can be compared in their own right. However, values expressed in different units should not be compared with each other. In general, the test provides quantitative results and measures anti-S antibodies, makes it easier to evaluate.

Effects of post-infection cellular immunity apart than antibodies: After COVID-19 infection, besides specific antibodies, cellular-mediated responses may also develop. Over time, the cellular response may continue much longer than the antibody response. However, it is not known whether all patients develop a protective immune response and how long this protective effect lasts. On the other hand, shortly after suffering COVID-19, cases of recurring COVID-19 have been reported, albeit rarely.

Persistence of developing antibodies: It is not known if all patients with COVID-19 develop protective antibodies or how long these antibodies persist. There are differences in the results of the studies conducted on the course of developed antibody responses against SARS-CoV-2. These different results may be due to the heterogeneous nature of the patients studied (such as asymptomatic, mild, or more severe diseases), or the use of different antibody tests in different studies. There are studies showing that patients with COVID-19 infection with asymptomatic or milder symptoms have much lower antibody levels and these antibodies disappear in a much shorter time. In one study, it was found that patients with mild symptoms and COVID-19 had lower antibody levels, but their neutralizing effects were similar to patients with moderate and severe disease. In addition, there are studies showing that neutralizing antibodies may not always develop in people with mild symptoms.

When looking at the pathogenesis of SARS CoV-2 infection, it can be considered that SARS-CoV-2 disease have both mucosal and systemic findings. We know that the older SARSCoV-1 and MERS-CoV infections had systemic and relatively more intense clinical pictures of symptomatic disease, compared to mild seasonal coronavirus infections. It can be concluded that SARS-CoV-1 and MERS-CoV infections had been shown to create stronger cellular immunity, and also to cause a stronger and longer-lasting antibody response. Therefore, it 
can be predicted that SARS CoV-2 infection with systemic symptoms may also lead to a longer-lasting immune response. In a study conducted in Bursa, it was shown that anti-N and anti-S antibodies persist for at least nine months after symptomatic infection (unpublished data). Indeed, some patient recovered from SARS-CoV-2 disease, have much more quantitative antibody levels than others. In regard of assessing plasma for therapeutic purposes, the FDA recommends the accepting of sera above certain antibody levels into the plasma pool, for the preparation of plasma for COVID-19 treatment. Accordingly, for example; Roche Elecsys Anti-SARS-CoV-2 total semi-quantitative/qualitative test results with COI (cut-off index) level $>109$, Roche Elecsys Anti-SARS-CoV-2 quantitative total antibody test with level $>132 \mathrm{IU} / \mathrm{mL}$, Euroimmune anti-SARS-CoV-IgG semi-quantitative/qualitative test with ratio $>3.5$, determined as acceptable high antibody values, for the convalescent plasma pool. However, it should be borne in mind that these thresholds are not protective threshold values, instead, are sufficiently high antibody levels recommended for plasma preparation. In a recent pre-print study; 498 seropositive persons who had the disease and 996 seronegative control subjects who did not have the disease were followed up for a median of 35 months. In follow up, in seronegative patients (without history of the COVID-19), the rate of PCR-positive COVID-19 infection was 15\%, while re-infection was $1 \%$ in seropositive individuals who had previous disease $(p=<0.001)$. Thus, recurrence rates of those who had the disease (seropositive) were $94 \%$ less than seronegative ones. If the question mentioned above is to be interpreted in the light of these data, in case of being seropositive by getting the disease, the possibility of re-infection may be around $1 \%$, in a period of approximately 9 months.

In summary, the answer to the question can be summarized as follows: If there is a symptomatic infection in the history, and if the type of antibody test studied has positive meaningful characteristics (such as, measuring the IgG or total antibodies directed against Anti-S, the test used has high specificity and sensitivity, the test gives high level quantitative results), it can be said that a protective response will be expected. We believe that if there is an adequate level of quantitative antibodies, protection can continue for months (e.g., at least 9 months), and the probability of re-infection will be as low as $1 \%$. However, this prediction should definitely not cause relaxation in COVID-19 protective measures, and protection measures should continue with the same meticulousness.

\section{References}

1. Caliendo AM, Hanson KE, Hirsch MS, Bloom A. Coronavirus disease 2019 (COVID-19): diagnosis. 2021. Available from: https://www.uptodate.com/contents/coronavirus-disease-2019-covid-19-diagnosis. Accessed date: 04 February 2021. [CrossRef]
2. Hansen $K E$, Caliendo AM, Arias CA, Englund JA, Hayden MK, Lee MJ, et al. Infectious diseases society of america guidelines on the diagnosis of COVID-19: serologic testing. 2020. Available from: https://www.idsociety.org/practice-guideline/covid-19-guideline-serology/. Accessed date: 21 January 2021. [CrossRef]

3. McIntosh K, Hirsch MS, Bloom A. Coronavirus disease 2019 (COVID-19): Epidemiology, virology, and prevention. 2021. Available from: $h$ ttps:// www.uptodate.com/contents/coronavirus-disease-2019-covid-19-epidemiology-virology-and-prevention. Accessed date: 21 January 2021. [CrossRef]

4. Lustig Y, Keler S, Kolodny R, Ben-Tal N, Atias-Varon D, Shlush E, et al. Potential antigenic cross-reactivity between SARS-CoV-2 and dengue viruses. Clin Infect Dis 2020; ciaa1207. [CrossRef]

5. Grifoni A, Weiskopf D, Ramirez SI, Mateus J, Dan JM, Moderbacher CR, et al. Targets of T cell responses to SARS-CoV-2 coronavirus in humans with COVID-19 disease and unexposed individuals. Cell 2020;181:1489501. [CrossRef]

6. Mateus J, Grifoni A, Tarke A, Sidney J, Dan JM, Burger ZC, et al. Selective and cross-reactive SARS-CoV-2 T cell epitopes in unexposed humans. Science 2020;370:89-94. [CrossRef]

7. Braun J, Loyal L, Frentsch M, Wendisch D, Georg P, Kurth F, et al. SARS-CoV-2-reactive $T$ cells in healthy donors and patients with $\mathrm{CO}$ VID-19. Nature 2020;587:270-4. [CrossRef]

8. Ng KW, Faulkner N, Cornish GH, Rosa A, Harvey R, Hussain S, et al. Preexisting and de novo humoral immunity to SARS-CoV-2 in humans. Science 2020;370:1339-43. [CrossRef]

9. Centers for Disease Control and Prevention (CDC). Interim guidelines for COVID-19 antibody testing in clinical and public health settings. 2020. Available from: https://www.cdc.gov/coronavirus/2019-ncov/ lab/resources/antibody-tests-guidelines. $h t m /$ ?delivery Name=USCDC_2067-DM29085. Accessed date: 29 January 2021. [CrossRef]

10. Bastos ML, Tavaziva G, Abidi SK, Campbell JR, Haraoui LP, Johnston JC, et al. Diagnostic accuracy of serological testss for COVID-19: systematic review and meta-analysis. BMJ 2020;370:m2516. [CrossRef]

11. Nivedhita G, Brundha MP. Eclia Test-Review. IJFMT 2020;14:5067-73. [CrossRef]

12. Chang L, Zhao J, Guo F, Ji H, Zhang L, Jiang X, et al. Comparative evaluation and measure of Accuracy of ELISAs, CLIAs and ECLIAs for he detection of HIV infection among blood donors in China. Can J Infect Dis Med Microbiol 2020; 2164685. [CrossRef]

13. SelfWH, Tenforde MW, Stubblefield WB, Feldstein LR, Steingrub JS, Shapiro NI, et al. Decline in SARS-CoV-2 antibodies after mild infection among frontline health care personnel in a multistate hospital network-12 states. MMWR Morb Mortal Wkly Rep 2020;69:1762. [CrossRef]

14. World Health Organization (WHO). Report of the WHO-China Joint Mission on Coronavirus Disease 2019 (COVID-2019). Available from: $h t t p: / /$ www.who.int/docs/default-source/coronaviruse/who-china-joint-mission-on-covid-19-final-report.pdf. Accessed date: 21 January 2021. [CrossRef]

15. Guo L, Ren L, Yang S, Xiao M, Chang D, Yang F, et al. Profiling early humoral response to diagnose novel coronavirus disease (COVID-19). Clin Infect Dis 2020; 71:778-85. [CrossRef]

16. Boonyaratanakornkit J, Morishima C, Selke S, Zamora D, McGuffin $S$, Shapiro $A E$, et al. Clinical, laboratory and temporal predictors of neutralizing antibodies to SARS-Cov-2 after COVID-19. J Clin Invest 2021;131(3):e144930. [CrossRef]

17. Gaebler C, Wang Z, Lorenzi JCC, Muecksch F, Finkin S, Tokuyama M, et al. Evolution of antibody immunity to SARS-CoV-2. Nature 2021; 591:639-44. [CrossRef] 
18. To KKW, Tsang OTY, Leung WS, Tam AR, Wu TC, Lung DC, et al. Temporal profiles of viral load in posterior oropharyngeal saliva samples and serum antibody responses during infection by SARS-CoV-2: an observational cohort study. Lancet Infect Dis 2020;20:565-74. [CrossRef]

19. Kovac M, Risch L, Thiel S, Weber M, Grossmann K, Wohlwend N, et al. EDTA-anticoagulated whole Blood for SARS-CoV-2 antibody testing by Electrochemiluminescence Immunoassay (ECLIA) and Enzyme-Linked Immunosorbent Assay (ELISA). Diagnostics (Basel) 2020;10:593.[CrossRef]

20. Deeks JJ, Dinnes J, Takwoingi Y, Davenport C, Spijker R, Taylor-Phillips S, et al. Antibody tests for identification of current and past infection with SARS-CoV-2. Cochrane Database Syst Rev 2020;6:CD013652.[CrossRef]

21. Wang $Y$, Zhang L, Sang L, Ye F, Ruan S, Zhong B, et al. Kinetics of viral load and antibody response in relation to COVID-19 severity. J Clin Invest 2020;130:5235-44.[CrossRef]

22. U.S Food and Drug Administration (FDA). Elecsys Anti-SARS-CoV-2. Available from: $h$ ttps://www.fda.gov/media/137605/download. Accessed date: 16 February 2021. [CrossRef]

23. U.S Food and Drug Administration (FDA). Elecsys Anti-SARS-CoV-2. Available from: https://diagnostics.roche.com/tr/tr/products/params/elecsys-anti-sars-cov-2-s.html. Accessed date: 03 February 2021.[CrossRef]

24. U.S Food and Drug Administration (FDA). Euroimmun Anti-SARS-CoV-2 ELISA (IgG) Instruction for use. Available from: https://www.fda.gov/ media/137609/download. Accessed date: 21 March 2021.[CrossRef]

25. U.S Food and Drug Administration (FDA). Euroimmun Anti-SARSCoV-2 QuantiVac ELISA (IgG). Available from: https://www.coronavirus-diagnostics.com/documents/Indications/Infections/Coronavirus/ El_2606_D_UK_E.pdf. Accessed date: 23 March 2021.[CrossRef]

26. To KK, Hung IF, Ip JD, Chu AW, Chan W, Tam AR, et al. COVID-19 re-infection by a phylogenetically distinct SARS-coronavirus-2 strain confirmed by whole genome sequencing. Clin Infect Dis 2020. Epub 2020 Aug 26.[CrossRef]

27. Tillett RL, Sevinsky JR, Hartley PD, Kerwin H, Crawford N, Gorzalski A, et al. Genomic evidence for reinfection with SARS-CoV-2: a case study. Lancet Infect Dis 2021;21:52-8.[CrossRef]

28. Long QX, Tang XJ, Shi QL, Li Q, Deng HJ, Yuan J, et al. Clinical and immunological assessment of asymptomatic SARS-CoV-2 infections. Nat Med 2020;26:1200-4.[CrossRef]
29. Zhao J, Yuan Q, Wang H, Liu W, Liao X, Su Y, et al. Antibody responses to SARS-CoV-2 in patients with novel coronavirus disease 2019. Clin Infect Dis 2020;71:2027-34.[CrossRef]

30. Chen $X$, Pan Z, Yue S, Yu F, Zhang J, Yang Y, et al. Disease severity dictates SARS-CoV-2-specific netralizing antibody responses in COVID-19. Nature 2020;5(1):80.[CrossRef]

31. Wang X, Guo X, Xin Q, Pan Y, Hu Y, Li J, et al. Neutralizing antibodies responses to SARS-CoV-2 in COVID-19 inpatients and convalescent patients. Clin Infect Dis 2020; 71(10):2688-94.[CrossRef]

32. Rijkers G, Murk JL, Wintermans B, Van Looy B, van den Berge $M$, Veenemans $J$, et al. Differences in antibody kinetics and functionality between severe and mild severe acute respiratory syndrome Coronavirus 2 infections. J Infect Dis 2020;222:1265-9.[CrossRef]

33. Lynch KL, Whitman JD, Lacanienta NP, Beckerdite EW, Kastner SA, Shy $B R$, et al. Magnitude and kinetics of anti-SARS-CoV-2 antibody responses and their relationship to disease severity. Clin Infect Dis 2021;72(2):301-8.[CrossRef]

34. Cao WC, Liu W, Zhang PH, Zhang F, Richardus JH. Disappearance of antibodies to SARS-associated coronavirus after recovery. N Engl J Med 2007;357:1162-3.[CrossRef]

35. Choe PG, Perera RAPM, Park WB, Song KH, Bang JH, Kim ES, et al. MERSCoV antibody responses 1 year after symptom onset, South Korea, 2015. Emerg Infect Dis 2017;23:1079-84.[CrossRef]

36. Wu $L P$, Wang NC, Chang $Y H$, Tian $X Y, N a D Y$, Zhan $L Y$, et al. Duration of antibody responses after severe acute respiratory syndrome. Emerg Infect Dis 2007;13:1562-4.[CrossRef]

37. Huang AT, Carreras BG, Hitchings MDT, Yang B, Katzelnick LC, Rattigan $S M$, et al. A systematic review of antibody mediated immunity to coronaviruses: kinetics, correlates of protection, and association with severity. Nat Commun 2020;11:4704.[CrossRef]

38. U.S Food and Drug Administration (FDA). Bowman NB. Convalescent Plasma EUA Letter of Authorization March 9, 2021. Available from: $h t t-$ ps://www.fda.gov/media/141477/download. Accessed date: 22 March 2021.[CrossRef]

39. Leidi A, Koegler F, Dumont R, Dubos R, Zaballa ME, Piumatti G, et al. Risk of reinfection after seroconversion to SARS-CoV-2: a population-based propensity-score matched cohort study. MedRxiv 2021.[CrossRef] 